\title{
Corela
}

Cognition, représentation, langage

HS-21 | 2017

Linguistique de corpus : vues sur la constitution, l'analyse et l'outillage

\section{Another Facet of Literary Similes : A Study of Noun +Colour Term Adjectives}

Suzanne Mpouli et Jean-Gabriel Ganascia

\section{(2) OpenEdition}

Journals

Édition électronique

URL : http://journals.openedition.org/corela/4817

DOI : $10.4000 /$ corela. 4817

ISSN : 1638-573X

Éditeur

Cercle linguistique du Centre et de l'Ouest - CerLICO

Référence électronique

Suzanne Mpouli et Jean-Gabriel Ganascia, " Another Facet of Literary Similes : A Study of Noun +Colour Term Adjectives », Corela [En ligne], HS-21 | 2017, mis en ligne le 20 février 2017, consulté le 19 avril 2019. URL : http://journals.openedition.org/corela/4817 ; DOI : 10.4000/corela.4817

Ce document a été généré automatiquement le 19 avril 2019

\section{cc) (†) (2)}

Corela - cognition, représentation, langage est mis à disposition selon les termes de la licence Creative Commons Attribution - Pas d'Utilisation Commerciale - Partage dans les Mêmes Conditions 4.0 International. 


\title{
Another Facet of Literary Similes : A Study of Noun+Colour Term Adjectives
}

\author{
Suzanne Mpouli et Jean-Gabriel Ganascia
}

\section{Introduction}

1 One of the main reasons that fictional texts succeed in resonating with their readers is their use of strong visual images which enable one to re-create a scene or to picture a character as if he or she were physically there. Colours, in particular, play a crucial role in shaping those visual images, not only because they make descriptions more vivid but also because a wide range of connotative meanings is culturally associated with specific colour terms. For example, whereas in the Western world, the colour 'black' is generally associated with death and mourning, in the Eastern world, this role is devoted to the colour 'white'. In addition, if the colour 'white' is generally linked to purity and goodness, its opposite 'black' evokes evil as well darkness and the colour 'red' can, depending on the circumstances, refer to fury, flame or even embarrassment (Philip, 2006). In this respect, the scarlet letter in Nathaniel Hawthorne's eponymous novel does not only indicate to others that the woman who wears it has committed adultery, but also keeps her in a state of perpetual shame, the colour scarlet being presented in the Bible as the colour of sin, the colour of the garment of the prostitute depicted in Revelations $17: 4$. Similarly, in $L a$ Comédie Humaine, Balzac adheres to a popular medieval belief by systematically assigning green, yellow or orange garments as well as physical attributes to his malevolent characters (Vanoncini, 2004).

2 As with word arrangement, writers have notably been known for how they manipulate colours either by giving them new connotative meanings or by exemplifying idiosyncratic colour usage worthy of a painter's palette. If we refer to what has been said earlier about the colour 'white' in the Western culture, the title of Webster's play, The White Devil 
sounds at first like an oxymoron. However, it takes all its meaning in the whole colour imagery of the play in which 'whiteness' is depicted as being the colour of hypocrisy and as such, far more deceptive than 'blackness' (Connolly \& Hopkins, 2015). Moreover, the semantic field of both concepts in that play shows that the idea of 'blackness' is conveyed not only through the colour adjective 'black' but also through its synonym 'dusky' and several compound nouns containing the word 'black' (blackbird, blacklust, blackthorn), whereas the adjective 'pale' is used as a synonym of 'white'. As a matter of fact, expressions of colours can take various forms in literary texts, from single nouns (the green of her eyes), verbs (embrown) and adjectives (sulphurous light) to compound adjectives (fiery-red complexion), noun phrases (the colour of tallow) and fully fledged similes (brown as a gipsy), depending on the impact and hue the author seeks to achieve. In terms of pictorial precision, it can be hypothesised that complex expressions of colours offer more creative liberties to writers as they make it possible to blend different colours (large eyes violet-bluey-blackish), to circumscribe the coloured area (red-faced) and even to pinpoint the intended shade of a particular colour by mentioning a prototypical object or phenomenon which possesses it (gem-green) ${ }^{1}$.

The present article is focused on the latter forms of complex expressions of colours that can either take the form of fully fledged similes (brown as a gipsy) or synthetic similes ( gem-green). Even though, unlike fully-fledged similes, synthetic ones are not built around a comparison marker, writers equally use both to communicate subtly with their readers by soliciting their imagination as well as their own perception of the colours of elements of the world. Thus, this paper intends to answer the following questions: Are synthetic similes use differently and do they fulfil a different stylistic purpose than fully fledged ones? What specific features distinguish creative synthetic similes? Finally, since synthetic similes combine a noun and a colour term, what can be said about the choice and the distribution of colour terms used by British writers?

\section{Background to the Study}

\section{Similes and the Use of Colours}

Similes can be defined as a type of figures of speech in which two or more entities or processes pertaining to very distinct semantic fields are explicitly compared to one another on the basis of stated or implied (dis)similarities, so as to produce a particular image in a person's mind. Because of their structure and their ability to make a statement more concrete by introducing common knowledge, they constitute an inherent part of everyday language. In fact, similes achieve different purposes in communication: they can be used of course to assess similarities, but also for comical purposes, to provoke thought or to clarify a point (Roberts \& Kreuz, 1994). In literary works, similes actively participate in rendering depictions and portrayals real, unforgettable or even surprising. Moreover, they are flexible enough to be effectively combined with other rhetorical figures such as metaphor, irony, hyperbole or alliteration (Shabat Bethlehem, 1996).

Since the beginning of rhetoric, similes have always been associated with metaphors not only because both are figures that rely on analogy but mainly because in most cases, one figure can easily be converted into the other by adding or removing the comparative or marker. It is, therefore, not coincidental that the terminology that applies to metaphor description has been extended to refer to simile components. In this respect, a fully 
fledged simile such as "Her cheeks are as red as roses" is generally divided into three main parts : a topic 'cheeks', a ground or salient trait 'red' and a vehicle 'roses'. However, it can be argued that the degree of figurativeness of that occurrence is lower than that of an open simile like "Her cheeks are as roses", which could rely on various other possible salient traits of roses such as their beauty, their delicateness, their warmth or their softness. Even though Ortony (1979) agrees that the similarity between the vehicle and the tenor in colour similes can also be built on attributes inherent to the colour itself such as hue, saturation and intensity, he argues that colour attributes are so high-salient that they tend to eclipse other common attributes shared by the vehicle and the topic and reduce the figurativeness so much so that the resulting simile is very close to a literal comparison. Addison (1993), on the contrary, still considers colour similes as similes albeit literal ones, since the compared entities do not belong to the same semantic field.

With regard to colour and figurative language, Philip (2006) notes that the high saliency of colours makes them rather adequate to be used in a figurative sense as they can only be successfully applied to apt and valid comparisons. Consequently, it is possible to distinguish between idiomatic colour similes which are fixed collocations in a given language whose meaning cannot be inferred from the combined meaning of its constituents, and their variations, creative colour similes, which explore more widely the spectrum of shades a particular colour can take. Moreover, for a creative colour simile to be easily understandable, it must ideally rely on shared cultural beliefs and use as vehicle an object that typically exemplifies that particular colour. In this respect, "whiter than dried rice" would be considered a fairly accessible variation of "whiter than white", the canonical English to express extreme righteousness, as it requires far less thought and processing than "whiter than next week's improved detergent", a more opaque variation of the same simile (Philip, 2006).

\section{Basic Colour Terms and English Literature}

7 In the field of optics, colours can be described as the way an eye's retina interprets a particular light wavelength (Dowman, 2001). Of course, in each natural language, some words also called colour terms (CTs) have been coined to discriminate between these perceived light wavelengths. Consequently, as language universals, colour names have often been used to compare conceptual systems of different languages and therefore, to fuel the debate on the arbitrary nature of meaning. Up until the influential work of Berlin and Kay (1969), the inconsistency and differences characterising colour separation in various languages were considered sufficient proof of the interindependence of linguistic semantic systems (Leech, 1981; Steinvall, 2002). Berlin and Kay (1969), however, notice that some colours are too easily translated between unrelated languages and set out to investigate whether it is simply coincidental. From their experiment on the mapping of basic colour terms in about 20 languages, they conclude that although the number of basic colour terms may vary from one language to another, these colour terms are always taken from a fixed set of eleven basic colour categories: 'white', 'black, 'red', 'green', 'yellow', 'blue', 'brown', 'purple, 'pink', 'orange' and 'grey'. A language such as English, for example, possesses all of these eleven basic colour terms, i.e. colour terms that are monolexemic, whose meaning is not included in another colour term, which can be applied to an unrestricted range of objects and are psychologically salient (Berlin \& Kay, 1969). In addition, these basic colour terms, irrelevant of the language, invariably follow the same order of appearance illustrated in Table 1. 


\begin{tabular}{|l|l|}
\hline LANGUAGE CHARACTERISTICS & COLOUR TERMS \\
\hline LANGUAGES WITH 2 COLOURS & white and black \\
\hline LANGUAGES WITH 3 COLOURS & white, black and red \\
\hline $\begin{array}{l}\text { LANGUAGES WITH } 4 \quad \text { OR } 5 \\
\text { COLOURS }\end{array}$ & white, black, red, green and/or yellow \\
\hline LANGUAGES WITH 6 COLOURS & white, black, red, green, yellow and blue \\
\hline LANGUAGES WITH 7 COLOURS & white, black, red, green, yellow, blue and brown \\
\hline $\begin{array}{l}\text { LANGUAGES WITH } 8 \text { OR MORE } \\
\text { COLOURS }\end{array}$ & $\begin{array}{l}\text { white, black, red, green, yellow, blue, brown, purple, pink, } \\
\text { orange } \text { and/or grey }\end{array}$ \\
\hline
\end{tabular}

Table 1. Basic colour term depending on the number of colours expressed in the language.

8 Several research works, however, have highlighted important biases that put into question the veracity and the objectivity of Berlin and Kay's results. The conception of the experiment, in particular, is often criticised, mainly because of the initial bias of the researchers, the lack of geographical diversity as well as adequate scanning of the participants (McIntyre, 2009), and the use of the Munsell chart which, besides being an American standard, limits the participants to an already predefined conception of colours (Dubois \& Grinevald, 1999). Moreover, Berlin and Kay's definition of colours has been qualified as being rather ethnocentric for two main reasons :

9 - it does not consider that, unlike English, some languages could have more than one term for a colour as in the case in Russian for blue or that some colour terms could be polysemous as it is the case in Scottish Gaelic (McIntyre, 2009);

10 - it restricts colours and consequently basic colour terms to chromatic properties, eliminating words denoting material entities used as colour terms such as it is the case in Jale, a language spoken in New Guinea, which does not possess a particular word for 'green' but uses "pianó", the name of a plant used to dye yarn, to refer the particular hues of green (Dedrick, 1998).

11 Despite these flaws in the methodology adopted, the influence of the Berlin and Kay's hypothesis (1969) on the linguistic community as a whole cannot be undermined, especially since their results are particularly precise with regard to the order in which colour terms become part of languages of the world. In this respect, its veracity has been tested against different languages as well as in written material such as literature and newspaper articles. By compiling the frequencies of colour terms from Pratt's analysis of the usage of colours by 17 British Romantic poets (1898) and those of two corpora, one of Chinese poetry and the other one of modern novels, McManus (1983) observes that all these frequencies strongly correlate the hierarchical order proposed by Berlin and Kay (1969). Besides, as far as poetry is concerned, the earlier a colour term has entered the English language, the more it is used by poets, which tends to suggest that more dated colour terms are more psychologically salient for poets and thus, are favoured either because they are more connoted and richer in meaning or either because of their 
synaesthetic properties. Moreover, even though some authors use some colours more extensively than others, the relative frequency of each colour per author remains constant overall.

In contrast, the same experience performed diachronically on a corpus of French novels, poems and plays published between 1500 and 2000 reveals two main facts :

13 - apart from 'blanc' ('white'),'noir' ('black') and 'rouge' ('red'), which are always respectively the first, the second and the third most frequent colour term used by French authors, the frequency order of the remaining colour terms does not really respect the Berlin and Kay's hypothesis (1969) and changes from one century to another;

14 - as time goes by, colour terms are more and more used in literary texts, which could be seen as proof either that literature reflects a world that produces a mass of objects that have to be differentiated by their colour or that conveying sensory experiences has gained more importance in literature (Cheminée, Dubois \& Resche-Rigon, 2006).

\section{Corpus and Method}

\section{Corpus Description}

15 In order to ensure linguistic homogeneity, only British novels published between the 19th and the mid-20th century were included in the corpus, spanning about 150 years. Apart from covering different literary periods, the resulting corpus combines different literary genres (historical novels, detective novels, adventure novels, novels of manners...). All novels were downloaded from the Project Gutenberg's main website ${ }^{2}$ and from the Project Gutenberg Australia's website ${ }^{3}$. Since only already digitised novels were considered, there exists, of course, a certain discrepancy in their distribution, as can be seen in Figure 1.

In total, sixty-two novelists were incorporated in the corpus, by observing a ratio of at least three novels per novelist. 1,188 novels and three short stories were thus put together, which roughly amounts to $152,941,750$ tokens.

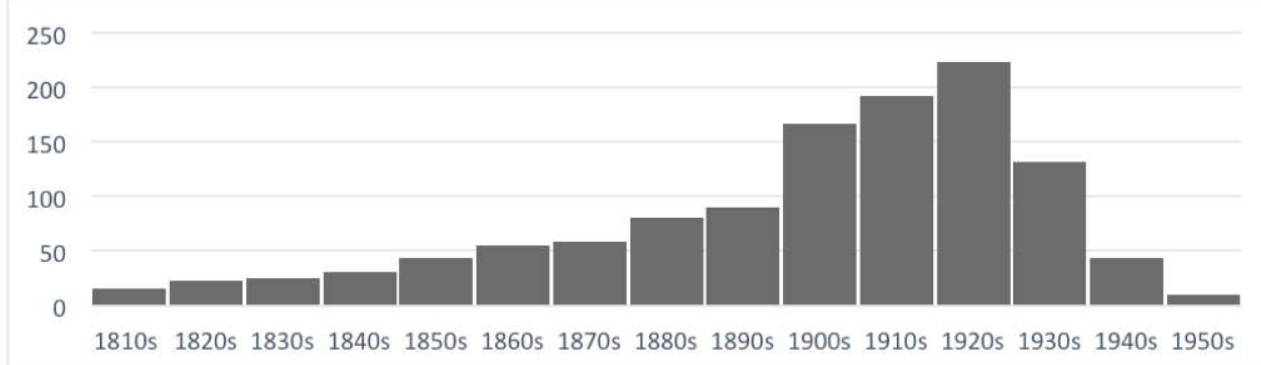

Figure 1. Distribution of the novels of the corpus per decade from the 1810s to the 1950s.

\section{Extraction Method}

In order to retrieve automatically all components of noun+CT similes in the corpus, we used a variation of the simile detection method described in Mpouli and Ganascia (2015). Basically, it consists of three main stages : segmenting the text into sentences, extracting sentences containing a noun $+\mathrm{CT}$ adjective in a sentence, and identifying the word in the sentence that adjective modifies. In this respect, each text was pre-processed with TreeTagger $^{4}$ (Schmid, 1994), a freely available multilingual tool which performs a wide 
range of natural language processing tasks : tokenisation, lemmatisation, part-of-speech tagging and syntactic chunking.

Sentence segmentation was done using the sentence boundaries defined by TreeTagger, which were eventually corrected by a set of manual rules for sentences that are disrupted by an ellipsis, a question or an exclamation mark.

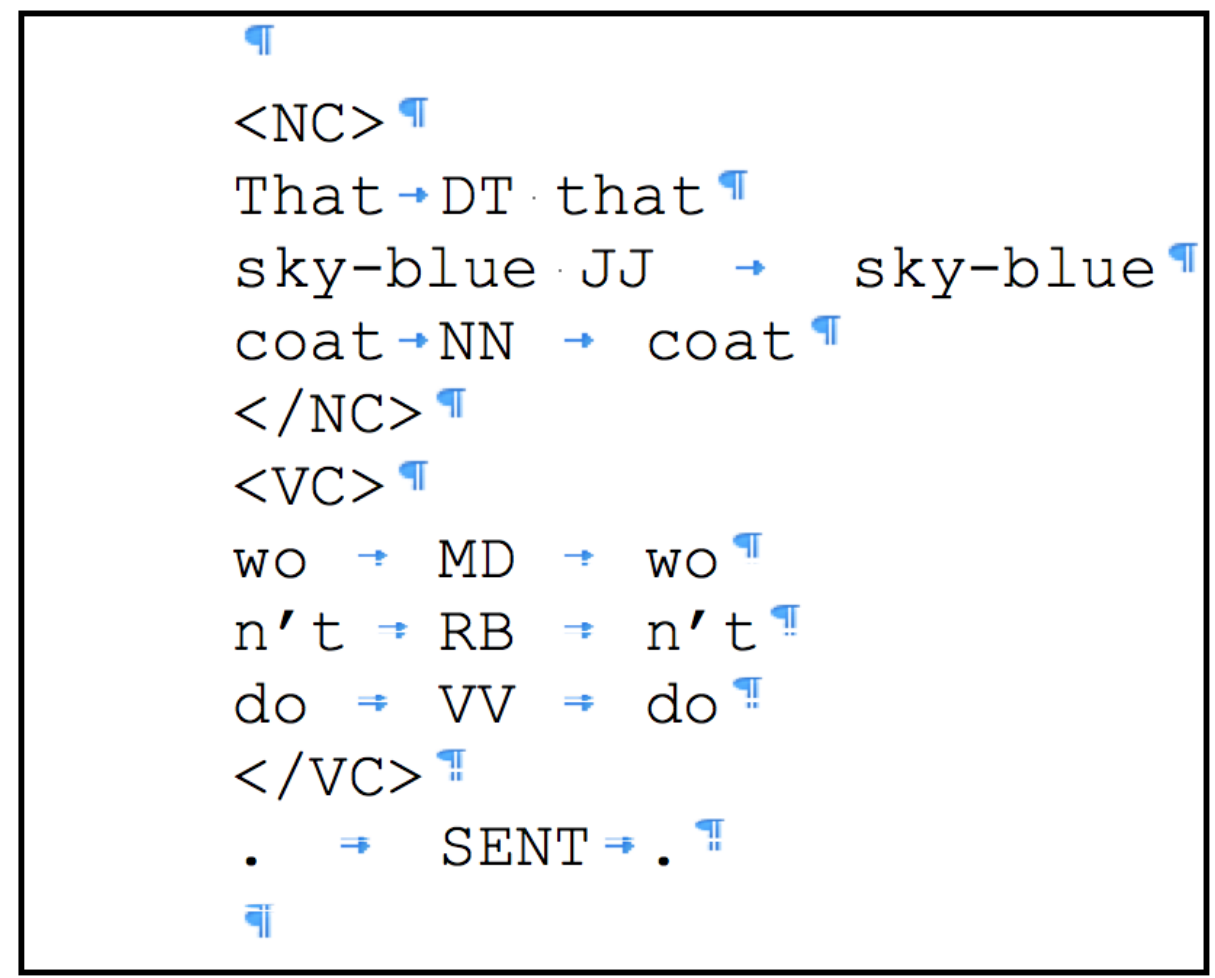

Figure 2. TreeTagger's output for the sentence "That sky-blue coat won't do." [W. H. Ainsworth, Rookwood (1834)]

Afterwards, all words of the form 'X-CT', i.e. words ending with one of the selected colour terms preceded by a hyphen were identified. For this experiment, in addition to the eleven English basic colour terms defined by Berlin and Kay (1969), 126 other colour terms were chosen (see table 3 for a complete list). Since the form 'X-CT' can correspond not only to noun+CT adjectives but also to noun+CT nouns, $\mathrm{CT}+\mathrm{CT}$ adjectives or nouns, a filtering had to take place.

\begin{tabular}{|l|l|}
\hline $\begin{array}{l}\text { Basic } \\
\text { CT }\end{array}$ & Related non-basic CTs \\
\hline white & silver*, eggshell, ivory, magnolia \\
\hline black & ebony, raven, sable \\
\hline red & $\begin{array}{l}\text { cardinal, carmine, carnation, cerise, cherry, cinnabar, claret, crimson, fuchsia, garnet, } \\
\text { magenta, maroon, murrey, roan, rubby, sandy, scarlet, stammel, vermeil, vermilion, } \\
\text { wine, heather*, coral* }\end{array}$ \\
\hline green & celadon, chartreuse, jade, myrtle, pistachio, verdigris, turquoise* \\
\hline
\end{tabular}




\begin{tabular}{|l|l|}
\hline yellow & $\begin{array}{l}\text { amber*, apricot*, buff, champagne, citrine, crocus, daffodil, flaxen, gilt, gold, golden, } \\
\text { jasmine, lime, maize, ocher, peach, primrose, saffron, sand, straw, sulfur, sulphur, } \\
\text { camel*, rust*, coral* }^{*}\end{array}$ \\
\hline blue & $\begin{array}{l}\text { aqua, azure, cerulean, indigo, lavender, mauve, periwinkle, sapphire, teal, violet, } \\
\text { indigo, azure, turquoise* }\end{array}$ \\
\hline brown & $\begin{array}{l}\text { amber*, auburn, bay, biscuit, bistre, bole, bronze, chestnut, chocolate, cinnamon, } \\
\text { tan, tawny, umber, beige*, burgundy*, rust*, camel }\end{array}$ \\
\hline purple & $\begin{array}{l}\text { burgundy*, eggplant, heliotrope, lilac, mulberry, orchid, petunia, plum, puce, } \\
\text { heather*, mauve }\end{array}$ \\
\hline pink & bisque, blush, damask, rosy, salmon, apricot*, rose \\
\hline orange & tangerine \\
\hline grey & beige*, ash, dove, pewter, slate, cineritious, drab, platinum, taupe, silver* \\
\hline
\end{tabular}

Table 2. All colour terms selected for the experiment (the asterisk signals colour term that also refers to the hue of another colour term)

20 In this respect, first, we used a machine-readable version of the Collaborative International Dictionary of English (CIDE) ${ }^{5}$ and a list of manually compiled negative triggers to delete all sentences in which $\mathrm{X}$ refers to a basic colour term, an adjective or a word assessing colours that possesses more than one lexical category such as "light" or "deep". The second and last stage, which was done manually and heavily relies on dictionaries and linguistic knowledge, concerns the removal of all cases in which :

21 - the previously identified X-CT word is used as a noun : (1) Will you wear the smoke-grey tonight, madam ? [A. E. W. Mason, The Summons (1920)];

22 - the X term is a prefix: (2) He meditated suits, with a sub-purple glow, shirts, handkerchiefs and ties to correspond. [H. G. Wells, You can't be too careful (1941)]

23 - the X-CT term designates a specific colour shade : (3) Why did she wear those white bands about her hair, and that butcher-blue wrapper and the white cuffs? [E. Wallace, The Fellowship of the Frog (1925)].

With this method, around 2,280 pertinent similes were found in all the novels in the corpus except the ones written by Jane Austen and Lewis Carroll. Next, the different components of these similes were automatically identified using hand-crafted rules. For obvious reasons, once the noun+CT adjective is known, the vehicle and the ground of the simile are very easy to determine : the former constitutes the first part of the noun+CT adjective, the lexeme that precedes the colour term, while the latter is the colour term.

As far as the detection of the topic is concerned, based on the structure of sentences in English, it is possible to derive the function of the topic in the sentence from the position of the adjective. For example, if the adjective is used attributively, it is generally immediately followed by the vehicle. All plausible scenarios are summarised in Table 3. 


\begin{tabular}{|l|l|l|}
\hline $\begin{array}{l}\text { Type } \\
\text { adjective }\end{array}$ & Position or Function & Example \\
\hline $\begin{array}{l}\text { Appositive } \\
\text { adjective }\end{array}$ & $\begin{array}{l}\text { Head of the noun phrase that } \\
\text { precedes or follows the } \\
\text { adjective }\end{array}$ & $\begin{array}{l}\text { (4) “The heavy face, now brick-red with summer } \\
\text { suns, did not change." [ J. Buchan, Witch-Word } \\
(1927)]\end{array}$ \\
\cline { 2 - 3 } $\begin{array}{l}\text { Attributive } \\
\text { adjective }\end{array}$ & $\begin{array}{l}\text { (5) The circle round the silver-grey mare } \\
\text { narrowed slowly. [J. Conrad, Nostromo (1904)] }\end{array}$ \\
\hline $\begin{array}{l}\text { Predicative } \\
\text { adjective }\end{array}$ & Verb subject or complement & $\begin{array}{l}\text { (6) Andrew's back was blood-red in the brazier } \\
\text { light. [T. Mundy, Old Ugly Face (1941)] }\end{array}$ \\
\hline
\end{tabular}

Table 3. Rules governing the identification of the topic (the noun+CT is underlined and the topic is in bold).

The retrieved topics were then reviewed manually and corrected when necessary. Finally, in addition to noun+CT similes, fully fledged colour similes built around the markers 'like', 'as', 'as...as', 'more...than' and 'less...than' were also extracted for comparison purposes using the same method and principles.

\section{Fully Fledged Colour Similes vs. Noun+CT Similes : Frequency and Stylistic Usage}

Three main facts concerning the results of the extraction task show that fully fledged colour similes and noun $+\mathrm{CT}$ similes are not used interchangeably :

- the corpus contains far more noun+CT similes than fully fledged colour similes (about 1,550 occurrences);

29 - the frequency of some colours terms differs drastically from one type of similes to another (see Figure 3);

30 - the most frequent prototypical vehicle for the same colour term also often varies from one type of simile to another as illustrated in Table 4. Similarly, some topics seem to be preferred depending on the type of similes used.

\begin{tabular}{|c|c|c|c|c|c|}
\hline \multirow[t]{2}{*}{$C T$} & \multirow[b]{2}{*}{$\begin{array}{l}\text { Prototypical } \\
\text { example(s) given in } \\
\text { the CIDE }\end{array}$} & \multicolumn{2}{|c|}{ Noun + CT Similes } & \multicolumn{2}{|c|}{ Full Fledged Colour Similes } \\
\hline & & $\begin{array}{l}\text { Most } \\
\text { Frequent } \\
\text { Noun+CT } \\
\text { Adjective }\end{array}$ & $\begin{array}{l}\text { Most Frequent } \\
\text { Topic(s) }\end{array}$ & $\begin{array}{l}\text { Most } \\
\text { Frequent } \\
\text { Topic(s) }\end{array}$ & $\begin{array}{l}\text { Most Frequent } \\
\text { Vehicle(s) }\end{array}$ \\
\hline white & snow & $\begin{array}{l}\text { snow-white } \\
(283 / 511)\end{array}$ & hair & & $\begin{array}{l}\text { death } \\
(109 / 629)\end{array}$ \\
\hline black & soot, coal & $\begin{array}{l}\text { coal-black } \\
(135 / 337)\end{array}$ & hair and horses & $\begin{array}{l}\text { People and } \\
\text { body parts }\end{array}$ & $\begin{array}{l}\text { night } \\
(71 / 448)\end{array}$ \\
\hline
\end{tabular}




\begin{tabular}{|l|l|l|l|l|l|}
\hline red & blood & $\begin{array}{l}\text { blood-red } \\
(244 / 326)\end{array}$ & $\begin{array}{l}\text { complexion } \\
\text { and light }\end{array}$ & & $\begin{array}{l}\text { blood } \\
(18 / 164)\end{array}$ \\
\hline $\begin{array}{l}\text { gray/ } \\
\text { grey }\end{array}$ & $\begin{array}{l}\text { pepper, salt, ashes, } \\
\text { hair whitened by age }\end{array}$ & $\begin{array}{l}\text { iron-grey } \\
(163 / 315)\end{array}$ & hair & - & $\begin{array}{l}\text { wing } \\
(4 / 22)\end{array}$ \\
\hline green & $\begin{array}{l}\text { growing plants or } \\
\text { grass }\end{array}$ & $\begin{array}{l}\text { sea-green } \\
(69 / 288)\end{array}$ & $\begin{array}{l}\text { linen } \\
\text { clothes and }\end{array}$ & places & $\begin{array}{l}\text { glass } \\
(7 / 37)\end{array}$ \\
\hline
\end{tabular}

Table 4. Pattern distribution of the 5 most frequent colour terms used in noun+CT similes. in similes, there is no correlation between the noun+CT similes and fully fledged colour similes: for the first type of similes, only instances of 'rose' (10),'bay' (1),'gold' (5), 'silver' (2), 'scarlet' (1), 'gilt' (1) and 'mauve' (2) were found, whereas for the second type, the ground of the simile is generally inflected forms of existing colour terms ('rosy' (17)', 'scarlet'(4),'bluish' (1), 'blond' (1), 'silver' (1) and 'greeny' (1)). It is worth noting that in both types of similes, the most frequent colour terms refer to the colour pink, surpassing even the frequency of the colour term 'pink' itself.

Grossly speaking, the frequency of occurrences of basic CTs in both types of similes (Figure 3) do not confirm the trend observed in McManus (1983) and thus, questions the Berlin and Kay's hypothesis. The frequency of the CTs used in noun+CT similes, especially, differ widely from their hypothesis: although 'white' is the most frequent $\mathrm{CT}$, it is followed directly by 'grey/gray' which should logically be the least frequent CT, while 'blue'and 'brown' are far more recurrent than 'yellow' and 'green'. On the contrary, as far as fully fledged colour similes are concerned, the hierarchical order proposed by Berlin and Kay (1969) is more or less strictly respected, apart from the frequency of 'blue' which surpasses that of 'yellow'.

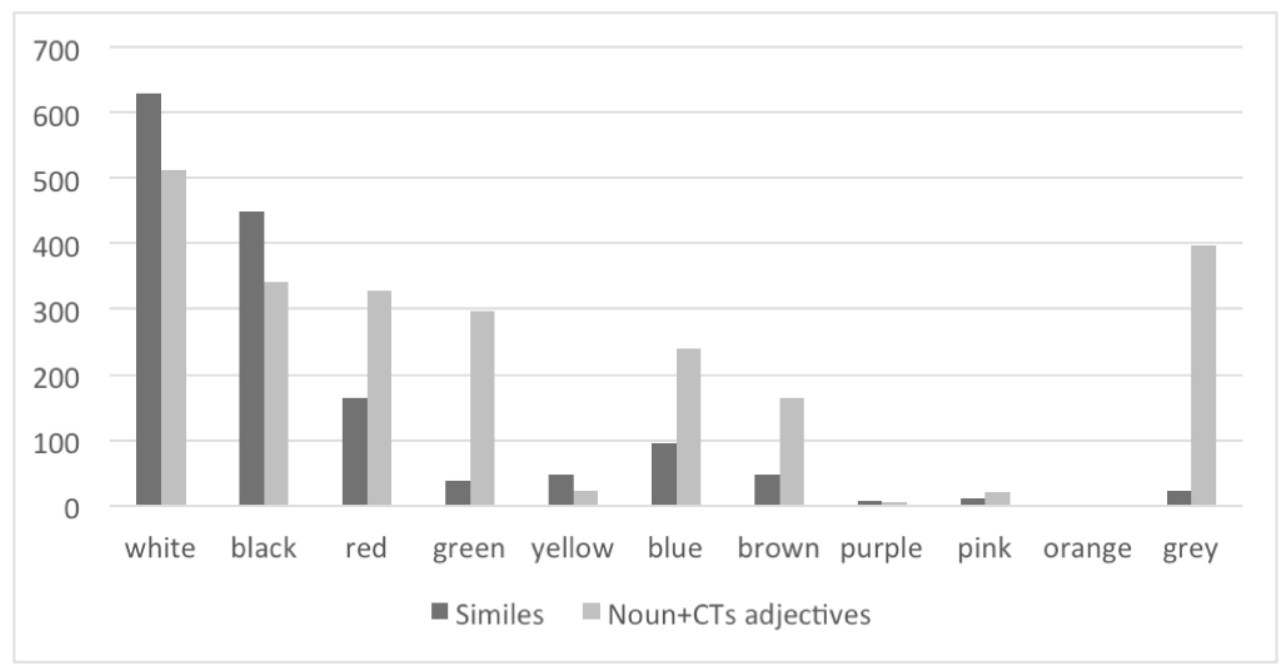

Figure 3. Colour term distribution in fully fledged colour similes and noun+CT similes

It seems obvious that the bulk of the selected non-basic CTs are not used in similes because they are not really connoted in the English language. Alongside connotation, the 
role of collocation and foregrounding cannot be undermined. Similes are successful when they are creative, surprise the readers and outline a behaviour or characteristic that the author wants to stress. In this respect, a simile that makes use of a prototypical vehicle is not very creative. Therefore, instead of wasting similes on minor background elements such as body parts, clothes or animals, authors tend to transform them into noun+CT similes, and in the process, make them less prominent in the sentence. That could explain why the frequency of 'blood-red' is more than ten times that of 'red as blood' or why there is a perceptible difference in meaning between (7) "But there was no lack of animation in her little steel-grey eyes, nor of decision in her manner" [J. Galsworthy, The Patrician (1911)] and (8) "Uncomfortable under those stern searching eyes that were as grey as steel and as cold, Pablo shifted on his feet, shrugged and put on a sneering brag"[R. Sabatini, Columbus (1941)]: whereas in the first sentence, the focus is on the colour of the eyes that resembles the colour of steel, in the second one, the simile highlights the coldness of the eyes that is reminiscent of the coldness of steel.

34 Apart from the semantic and conceptual differences between noun+CT and fully fledged colour similes, a close study of the extracted sentences also shows some restrictive uses of each type of similes. Unlike their counterparts, fully fledged similes make it possible :

- to combine the colour term with a second ground that enhances its meaning: (9) The room was vacant; the room was black and silent as a dungeon. [G. Meredith, The Tragic Comedians (1880);

36 - to emphasise the purity or the brightness of the colour through a hyperbole : (10) They went home in a motor-bus and a cloud of dust, with the heaven bluer than blue above, the hills dark and fascinating, and the land so remote seeming. [D. H. Lawrence, Kangaroo (1923)] ;

- to take advantage of the connotative meaning of the colour term : (12) He looked as black as night when he caught sight of us [E. Glyn, Red Hair (1905)].

38 In contrast, since noun $+\mathrm{CT}$ adjectives are compound adjectives, writers exploit this structure to create innovative and striking associations that go far beyond merely describing a colour hue. The corpus therefore contains :

\section{Metonymical similes}

39 In these similes, the topic refers to a part or a quality of the vehicle. In examples (12) and (13), it would not make any sense to simply transform the noun+CT as CT+noun simile to obtain teeth as white as an animal or eye as grey as a fish. In both sentences, the flexibility of English syntax is used to coin new adjectives and create a dual meaning. As a matter of fact, apart from meaning that the teeth are as white as an animal's, "animalwhite teeth" also implies sharpness and ferocity. Similarly, while the expression "rat-brown eyes" suggests slyness because of the connoted meaning of the word "rat", in "velvet-green moss", velvet evokes the inherent softness of the fabric which is lent to the moss.

(12) They longed-or dreaded-to stand within that huge cavern of blue lonely ice and hear the waves of the Polar Sea lick up the snow ; to taste that sugary cane with animal-white teeth, and feel the fluffy cotton between thick, lumpy fingers; to swim under water and look up instead of down; to crawl fearfully a little nearer to the molten centre of the planet through smoke and fire and awful thundering explosions. [A. Blackwood, The Promise of Air (1918)]

(13) The Reverend Mr. Arbroath started indignantly, and stared so hard that his ratbrown eyes visibly projected from his head. [M. Corelli, The Treasure of Heaven (1906)] 
(14) They had rested here; he sitting on the weatherworn parapet of the bridge; she leaping over it, and idly dropping bits of velvet-green moss into the whirl of clear brown water below. [W. Black, MacLeod of Dare (1878)]

\section{Cause and effect similes}

This type of similes generally associates a natural element or phenomenon such as the sun or the winter to the colour it casts on a particular entity.

(15) "I think I shall go and bathe," said Miss Inger, out of the cloud-black darkness. [D. H Lawrence, The Rainbow (1915)]

(16) With strong weather-brown fingers she tried to close the tiger's staring eyes. [T. Mundy, Full Moon (1935)]

(17) She basked with him on the edge of a rock and gazed over the ten-or was it twenty?miles of snowy wilderness; then they turned their tinted glasses on the knife-edge of the Jungfrau summit, its outline crystal-yellow against a storm-green sky. [J. Hilton, Contago (1932)]

\section{Reinvented conventional noun+CT similes}

These similes play on the various colours some objects can have in the universe and call into question the supremacy of the colours predominantly used with that vehicle (cf. Table 5).

\begin{tabular}{|c|c|}
\hline & Proposed Alternative(s) \\
\hline $\begin{array}{l}\text { iron-grey/ } \\
\text { iron-gray }\end{array}$ & $\begin{array}{l}\text { (18) The blue sky settled against them nakedly; they were leafless and lifeless save for the } \\
\text { iron-green shafts of the organ cactus, that glistened blackly, yet atmospherically, in the } \\
\text { ochreous aridity. [D. H. Lawrence, The Plumed Serpent (1926)] } \\
\text { (19) A single tent stood in a gully running from one of the gravel-pits of the heath, near an } \\
\text { iron-red rillet, and a girl of Kiomi's tribe leaned over the lazy water at half length, striking } \\
\text { it with her handkerchief. [G. Meredith, The Adventures of Harry Richmond (1871)] }\end{array}$ \\
\hline $\begin{array}{l}\text { peacock- } \\
\text { blue }\end{array}$ & $\begin{array}{l}\text { (20) The only light other than stars glowed through one peacock-green curtain in the } \\
\text { upper part of the building, marking where Dr. Emerson Eames always worked till morning } \\
\text { and received his friends and favourite pupils at any hour of the night. [G. K. Chesterton, } \\
\text { Manalive (1912)] }\end{array}$ \\
\hline ink-black & $\begin{array}{l}\text { (21) The lush, dark green of hyacinths was a sea, with buds rising like pale corn, while in } \\
\text { the riding the forget-me-nots were fluffing up, and columbines were unfolding their ink- } \\
\text { purple ruches, and there were bits of blue bird's eggshell under a bush. [D. H. Lawrence, } \\
\text { Lady Chatterley's Lover (1928)] }\end{array}$ \\
\hline $\begin{array}{l}\text { bottle- } \\
\text { green }\end{array}$ & $\begin{array}{l}\text { (22) He looked up towards the ingenuous, protruding, shining, liquid, bottle-blue eyes of } \\
\text { Thomas Johnson... [Ford, No More Parades (1925)] }\end{array}$ \\
\hline
\end{tabular}

Table 5. Examples of reinvented conventional noun $+\mathrm{CT}$ similes 


\section{Unfamiliar noun+CT associations}

The last type concerns the more opaque noun+CT similes which make use of unusual colour associations, so much so that the readers need to use a significant amount of imagination to understand them.

(23) The dark forest of karri that ran to the left of Wandoo away on the distant horizon, cut a dark pattern on the egg-green sky. [D. H. Lawrence, The Boy in the Bush (1924)]

(24) The fly-driver touched his age-green hat with his whip. [F. M. Ford, Some Do Not (1924)]

(25) "Then he stooped down, and put his lips to the cold clay-blue forehead." [A. Trollope, Ralph the Heir (1871)]

Overall, while on the one hand, noun $+\mathrm{CT}$ adjectives are used to perpetuate prevailing noun-colour combinations, on the other hand, they seem to provide to British novelists more latitude to play around and to show that colours are not as fixed as we think in the surrounding world. Like fully fledged similes, are noun+CT similes also made up of traditional and creative similes? What can they tell us about the period in which they were written?

\section{Noun+CT Similes and Creativity}

Creativity is key question in literature, especially as far as stylistic devices are concerned. At first glance, frequency and fixedness seem to be pretty good criteria to judge how creative a noun+CT adjective is. The rationale, in this case, is fairly simple : if a term is only used by one writer, it is highly plausible that it is a creative noun+CT adjective. However, it is important to also take into consideration the collocations existing in the language. For example, 'ebony-black' appears only once in the corpus whereas 'black as ebony' occurs 18 times, which suggests that it is a fairly common expression. Consequently, so as to objectively measure creativity in noun+CT adjectives, fully fledged colour similes must definitely be considered in order to get the broadest picture.

From the extracted results, we distinguish three main groups of noun+CT adjectives. The first group is made up of lexicalised noun+CT compounds that have entered the dictionary ; they are generally the most frequent ones and their vehicle is almost never combined with another CT. Apt examples would be compounds such as "jet-black" (119 occurrences), "bottle-green" (43 occurrences) and "nut-brown" (48 occurrences).

The second group comprises semi-lexicalised noun+CT compounds that convey images that are shared by different authors without exhibiting the same fixedness as adjectives of the first group. Examples of adjectives of this group include "amber-brown" (3 occurrences/3 authors), "coffee-brown" (3 occurrences /3 authors) and "apple-red" (4 occurrences $/ 3$ authors).

The last group contains creative or original noun+CT compounds. These are compound adjectives that appear generally once in the corpus or are used several times by the same author and do not correspond to a fully fledged colour simile. Some examples are "deathblue eyes", [D.H. Lawrence, Aaron's Rod (1922)], "phantom-grey yacht" [W. Black, Donald Ross of Heimra, 1891], "lamp-black lashes" [J. Galsworthy, Fraternity (1909)]. This group can be further divided into three subgroups: reinvented noun+CT similes, literal noun+CT similes and metaphorical noun+CT similes. As reinvented noun $+\mathrm{CT}$ similes have already 
been explained in the previous section, we will focus here only on the two remaining noun+CT similes.

Literal noun+CT similes are essentially descriptive as the colour term expresses a salient trait of the vehicle. The vehicle must normally be fairly well known to the readers and is often a vegetal entity or an animal. Examples include "pansy-blue eyes" [G. Griffith, The World Masters (1902)], "reseda-green chiffon" [A. E. W. Mason, At the Villa Rose (1910)]", “ lizard-green emerald" [E. P. Oppenheim, The Ostrekoff Jewels (1932)], "plumbago-grey suit" [D. H. Lawrence, The Lost Girl (1920)].

In contrast, metaphorical noun+CT similes occur mainly when the vehicle or the tenor is an abstract entity and is, therefore, by definition colourless such as in :

(26) It was a weird scene, full of definite detail, fascinating detail, yet all in the funeral-grey monotony of the bush. [D. H. Lawrence, Kangaroo (1920)]

(27) That brilliant bird the Baron, whose velvet coat and knickerbockers were the astonishment of Boscastle, instinctively drew near to Christabel, whose velvet and sable, plumed hat, and point-lace necktie pointed her out as his proper mate-Little Monty, Bohemian and décousu, attached himself as naturally to one of the Vandeleur birds, shunning the iron-grey respectability of the St. Aubyn breed. [M. E. Braddon, Mount Royal (1882)].

Another interesting point about creative similes is the discrepancy between the 17 contained in the 647 novels by 19th-century writers and the 130 found in the 1682 texts written during $20^{\text {th }}$ century, a fact that could be correlated to the different periods to which these novels belong. In fact, while the first group of novels corresponds roughly to the Victorian period (1837-1900) which saw the emergence of a true novelistic tradition, the second group falls under the Modernist period (1901-1953), a period in which writers feel committed to depicting the world as it is, as accurately as possible :

And art itself may be defined as a single-minded attempt to render the highest kind of justice to the visible universe, by bringing to light the truth, manifold and one, underlying its every aspect. It is an attempt to find in its forms, in its colours, in its light, in its shadows, in the aspects of matter and in the facts of life what of each is fundamental, what is enduring and essential-their one illuminating and convincing quality-the very truth of their existence. (Conrad, 1914, p. vii).

51 In order to verify whether the frequency of noun+CT similes as a whole differs from the Victorian to the Modernist period, we compared the relative frequency of colour terms per decades, the relative frequency of noun+CT similes, the relative frequency of creative noun+CT similes and the lexical diversity of vehicles used. All these relative frequencies were computed each time by dividing the number of occurrences by the number of tokens in the novels pertaining to each literary period. The lexical diversity of vehicles is based on the type/token ratio, a formula often used to measure lexical diversity. However, in this case, it is the number of individual vehicles which is divided by the total number of vehicles per colour. 


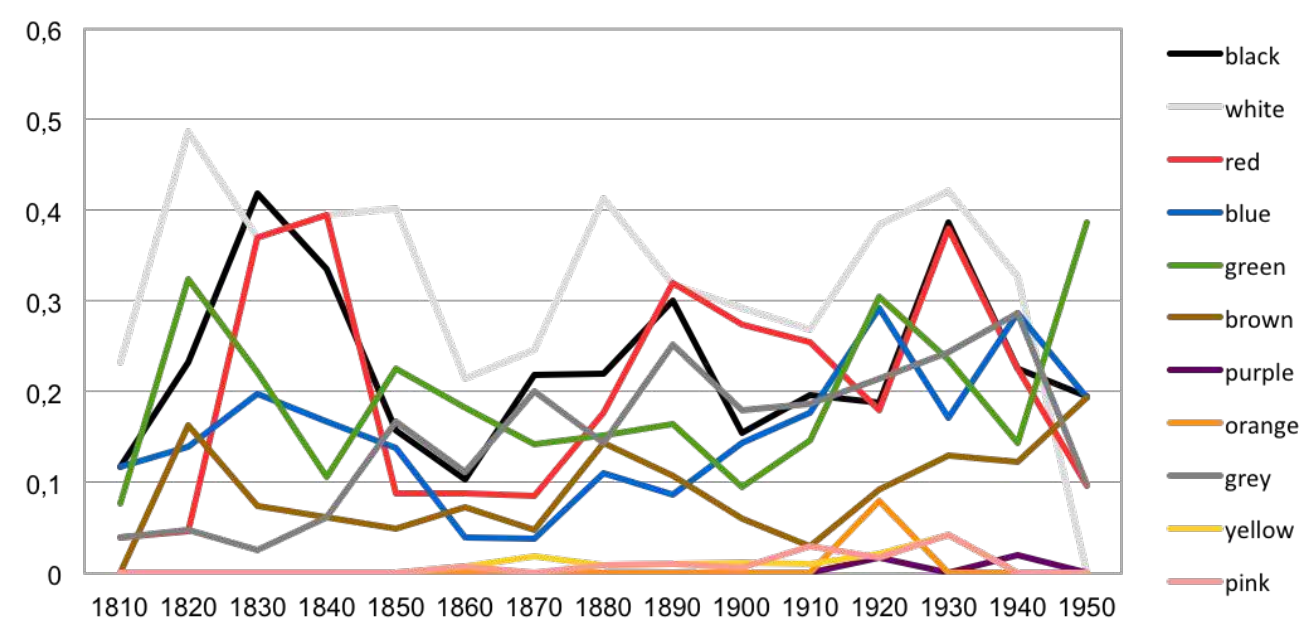

Figure 4. Relative frequency of each colour term per decade. with colours that are cognitively associated with rather salient vehicles such as 'white', 'black', 'red' and 'grey'. For all these colours, even though the predominant vehicle is still the most frequently used in Modernist novels, there is also a wide range of new vehicles introduced (e. g. 'hearse' with black, 'egg' with 'white', 'fire' with 'red' and 'skeleton' with 'grey'). In contrast, it is possible to infer from its lexical diversity that the colour 'purple' is the least connoted.

\begin{tabular}{|l|l|l|}
\hline & Victorian & Modernist \\
\hline white & 0.06 & 0.14 \\
\hline black & 0.06 & 0.12 \\
\hline red & 0.08 & 0.12 \\
\hline
\end{tabular}




\begin{tabular}{|l|l|l|}
\hline green & 0.11 & 0.21 \\
\hline yellow & 0.53 & 0.6 \\
\hline blue & 0.12 & 0.25 \\
\hline brown & 0.2 & 0.5 \\
\hline purple & 0 & 1 \\
\hline pink & 0.33 & 0.23 \\
\hline orange & 0 & 0.5 \\
\hline grey & 0.09 & 0.15 \\
\hline Average & 0.17 & 0.34 \\
\hline
\end{tabular}

Table 6. Lexical diversity per colour for both literary periods

59 If all these results tend to confirm the initial hypothesis about the important place of noun $+\mathrm{CT}$ similes in Modernist novels and confirm Lawrence's obsession with colours, they also suggest that the use of colours in general is far from being static, especially in diachronic experiments.

\section{Conclusion}

This article intended to examine noun $+\mathrm{CT}$ similes in a corpus of British fictional texts in order to study their usage and how they differ from fully fledged colour similes. From the results obtained, there is no doubt that although both structures are similes, they function differently: while traditional similes are strongly governed by collocations and can be used figuratively more easily, noun $+\mathrm{CT}$ similes typically provide background information. This dichotomy could perhaps explain why they also differ in their use of colours, confirming the idea that colours should not be taken in abstraction, but must be studied in a specific context. Furthermore, from the extracted noun+CT similes, a classification has been drawn that takes into account their originality. It has also been shown that despite being relegated to background elements, noun+CT similes actively participate in shaping depictions of Modernist novels. In addition, writers often take advantage of the fact that noun+CTs are compound adjectives in order to propose new daring semantic associations and to project the connotative meaning of the colour term on the word modified by the compound adjective. Whether the images thus created are really accessible to the readers should be interesting to test as they require in some cases either a solid culture or a vivid imagination.

\section{Acknowledgments}

61 This work was supported by French state funds managed the ANR within the Investissements d'Avenir programme under the reference ANR-11-IDEX-0004-02. 


\section{BIBLIOGRAPHIE}

Addison, C. (1993). From literal to figurative : An introduction to the study of simile. College

English, 55(4), pp. 402-419.

Berlin, B. and Kay, P. (1969). Basic Colour Terms : Their Universality and Evolution. Berkeley and Los Angeles : University of California Press.

Cheminée, P., Dubois, D. and Resche-Rigon, P. (2006). Couleur de pensée, couleur du temps. Penser la couleur et variations diachroniques du lexique de la couleur. Les Couleurs en question, pp. 23-45.

Connolly, A. and Hopkins, L. (2015). A Darker Shade of Pale : Webster's Winter Whiteness. E-rea, 12(2). Retrieved from http://erea.revues.org/4483 ; DOI : 10.4000/erea.4483.

Conrad, J (1914). Preface. The Nigger of the Narcissus : A Tale of Forecastle. New York:

Doubleday, Page \& Company.

Dedrick, D. (1998). The Foundations of the Universalist Tradition in Colour-Naming Research (and their Supposed Refutation). Philosophy of the Social Sciences, 28 (2) : pp. 179-204.

Dowman, M. (2001). A Bayesian Approach to Colour Term Semantics. Technical Report: The University of Sydney.

Dubois, D. and Grinevald C. (1999). Pratiques de la couleur et dénominations. Faits de langues, (14), pp 11-25.

Leech, G. (1981). Semantics : The Study of Meaning. Bungay : Penguin Books.

McIntyre, W. J. M. (2009). A Retrospective Survey of the Problems with Berlin and Kay (1969). California Linguistic Notes, 24(1). http://english.fullerton.edu/publications/clnArchives/pdf/ber lin \%20 \%20kay-R.pdf

McManus, I. C. (1983). Basic Colour Terms in Literature. Language and Speech, 26, 243-252.

Mpouli, S. and Ganascia, J.-G. (2015). "Pale as death" or "pâle comme la mort" : Frozen similes used as literary clichés. EUROPHRAS 2015. To be published.

Ortony, A. (1979). Beyond Literal Similarity. Psychological Review, 86, pp. 161-180.

Peprnik, J. (1996). Cold Colours in 19th-century English Literature. Contemporary Linguistics, 41-42 (1/2), pp. 503-517.

Peprnik, J. (2000). Warm Colours in 19th-century English Literature. Philosophica, 73, pp. 13-31.

Philip, G. (2006). Connotative meaning in English and Italian Colour-Word Metaphors.

Metaphorik, 10, pp. 59-93.

Pratt, A. E. (1898). The Use of Color in the Verse of the English Romantic Poets. Chicago : The University of Chicago Press.

Roberts, R. M. and Kreuz, R. J. (1994). Why do people use figurative language ? Psychological Science, 5(3), pp. 159-163.

Schmid, H. (1994). Probabilistic part-of-speech tagging using decision trees. Proceedings of the International Conference on New Methods in Language Processing, pp. 44-49. 
Shabat Bethehem, L. (1996). Simile and figurative language. Poetics Today, 17(2), pp. 203- 240.

Steinvall, A. (2002). English Colour Terms in Context. Ph.D. Dissertation. Umeå University : Skrifter från moderna språk 3.

Vanoncini, A. (2004). Balzac et les couleurs. L'Année balzacienne 1/2004 (5), pp. 355-366.

\section{NOTES}

1. All examples are taken from Peprnik (1996) and Peprnik (2000).

2. https://www.gutenberg.org/

3. http://gutenberg.net.au/

4. http://www.cis.uni-muenchen.de/ schmid/tools/TreeTagger/

5. This dictionary combines three main sources: the 1913 Webster's Revised Unabridged Dictionary, its supplement and data from Wordnet, a lexical ontology of English developed in the early 1990s. The project can be consulted at https://www.ibiblio.org/webster/.

\section{RÉSUMÉS}

Les comparaisons figuratives peuvent être introduites en anglais non seulement par des comparatifs mais aussi en combinant un nom et un terme de couleur pour former un adjectif composé du type "lily-white" ou "hearse-black". Ce travail étudie ce type de comparaisons figuratives dans un corpus de fiction britannique $\mathrm{du} 19^{\mathrm{e}}$ et $\mathrm{du} 20^{\mathrm{e}}$ siècle en se focalisant sur leur structure et leur contexte d'utilisation. Plus concrètement, il s'agit de déterminer si, tant au niveau de leur distribution que de leur emploi stylistique, ces termes de couleur se distinguent des comparaisons figuratives traditionnelles employant des couleurs. En outre, il est proposé une classification de ces adjectifs de couleur en fonction de leur originalité.

Similes can be expressed not only by using comparatives but also through noun+colour term (CT) adjectives such as "lily-white" or "hearse-black". This work studies such adjectives in a corpus of British prose fiction from the 19th- and 20th-century in terms of their structure and context of use. More specifically, it seeks to determine how similes built with those adjectives differ from traditional colour similes as far their distribution and their stylistic usage are concerned. In addition, it proposes a framework to classify noun $+\mathrm{CT}$ adjectives based on their originality.

\section{INDEX}

Mots-clés : Termes de couleur, comparaison figurative, fiction britannique du 19e et du 20e siècle, hypothèse de Berlin and Kay, adjectif composé

Keywords : Colour terms, Simile, 19th- and 20th-century British novels and short stories, Berlin and Kay's hypothesis, compound adjective 
AUTEURS

SUZANNE MPOULI 